\title{
Cupping: A Healing Method in West Sumatra (Indonesia) A Semiotic Perspective
}

\author{
Alexander Stark ${ }^{1}$ \\ ${ }^{1}$ Faculty of Language Studies and Human Development, Universiti Malaysia Kelantan, Malaysia \\ Correspondence: Alexander Stark, Faculty of Language Studies and Human Development, Universiti Malaysia Kelantan, \\ Taman Bendahara, Pengkalan Chepa, 16100 Malaysia.
}

Received: December 4, 2021

doi:10.11114/ijsss.v10i1.5417
Accepted: December 27, 2021

Available online: December 29, 2021

URL: https://doi.org/10.11114/ijsss.v10i1.5417

\begin{abstract}
This article investigates cupping a widespread traditional healing method in West Sumatra. However, the way cupping is used in some areas of the Malay-speaking region is unique in the sense that it uses buffalo horns during the cupping process. The author argues that for the matrilineal society of the Minangkabau in West Sumatra, the buffalo horn has a special connotation as it is crucial in many elements of their culture. By considering a semiotic research approach, the author wants to offer a new perspective on the Minangkabau and their culture. By doing so, the author intends to participate in the discussion about signs and symbols in the field of Minangkabau studies. In qualitative research that comprised fieldwork, traditional healers were observed and interviewed. The peculiar cupping technique was analysed, and a semiotic perspective seemed most fitting. It was detected that the usage of horns contains a specific meaning for the Minangkabau culture.
\end{abstract}

Keywords: cupping, ethnomedicine, semiotics, traditional healer, West Sumatra

\section{Introduction}

\subsection{Cupping in West Sumatra: Introductory Words}

Cupping is a healing method that can be found in many traditional healing systems. For example, in Islamic medicine, cupping is well-known and considered to belong to the traditions of Prophet Muhammad.

The Minangkabau society in West Sumatra, Indonesia, is part of the Islamic world. In so far, it is not surprising that cupping could be found in this region of the world too. Yet, the way the traditional healers use it differs from other regions due to the usage of buffalo horns. The author argues that the way how cupping is used in West Sumatra has a symbolic meaning and can be analysed in a semiotic way. Such a way could help to get a further perspective in the field of Minangkabau studies.

When Frederick Errington published his work about the Minangkabau (Errington, 1984), a controversy arose as he concluded that the Minangkabau society is using signs instead of symbols. In this article, this discussion will be taken up and discussed. For such a discussion, it will be important to look at the features of a sign in the sense of Errington.

The hypothesis for this research consists of two parts. First, it is assumed that the usage of buffalo horns has a special meaning for the Minangkabau society. Second, it is suspected that a semiotic approach can help to get background information which will enable to get a further perspective in the field of Minangkabau studies.

\subsection{Relevance of this Research}

This research is looking into cupping from the field of semiotics. It is intended to encourage medical practitioners to consider that semiotics can be helpful in understanding patients, symptoms and even healing methods. This point was emphasized by Nessa:

Semiotic interpretations put scientific medicine in a wider context. Semiotics analyzes and interprets what happens with man as a social being, interacting with others in an intersubjective way. (Nessa, 1996, p. 375)

Furthermore, it must be added that the discussion about signs is of importance in the field of Minangkabau studies as the already mentioned assumption of Frederick Errington is controversial. Is the Minangkabau society merely using signs, or are there symbols as well? This discussion should be picked up in order to offer a different perspective. 


\subsection{Literature}

The Minangkabau society is one of the largest matrilineal societies worldwide. So, it is not surprising that many scientific publications describe this society. Some publications investigate gender-specific contents (for example, Sanday, 2002 or Nasir et al., 2021) or social organization (for instance, Kahn, 1980). However, this article focuses on one element of traditional healing methods amongst the Minangkabau, namely cupping. The usage of horns can be found in other societies of the Malay-speaking world as well, and cupping is a very popular healing method in that area. This fact can be seen by the publication of the Malaysian Health Ministry (2013), which outlines the way how the healer should use cupping.

A fascinating article about cupping, in general, was written by Risniati et al. (2019). It investigates that topic from a biomedical perspective. The authors stress that cupping has many health benefits. This was also emphasized by El Sayed et al. (2013). A similar biomedical approach was published by Aboushanab \& AlSanad (2018). In this article, the authors stress that cupping is a treatment method that is relatively safe.

Only a few works of literature are available that describe the traditional Minangkabau medicine. One article that was published in recent years is the article of Stark (2019). His article gives a general overview of the traditional healing system. Lajtai (2003) is another scientist who focused on the traditional healer (dukun). However, he is also general without going into detail. Both articles give a good impression of the traditional Minangkabau healing system, but healing methods were not explained in detail. Moreover, the healing technique of cupping was not their primary research focus.

\subsection{Research Objectives}

By looking at the literature, it becomes evident that cupping is a crucial alternative treatment method. Moreover, it is considered as part of traditional Islamic medicine. The Minangkabau society is an Islamic society. Nonetheless, there is practically no analysis or description of how this society practices cupping. So, the first objective was as follows:

a) To describe the way how the Minangkabau healers conduct cupping.

Furthermore, it was striking that the traditional healers used horns for the bloodletting process. Therefore, the researcher had to search for a suitable method for the analysis. In the field of theoretical medicine, semiotics might offer a further point of view (Nessa, 1996). Interestingly it was detected that the discussion about signs and symbols is quite crucial. Often, traditional scholars and writers stress the symbolism of certain traditional elements. When Frederick Errington published his research and stressed that the Minangkabau society is more sign-oriented, a discussion was the consequence. Therefore, the second objective was as follows:

b) To offer a new perspective in the sign/symbol discussion in the field of Minangkabau studies by analysing the cupping method.

The cupping method is a traditional healing technique that is widespread. However, the regional context of West Sumatra contains interesting features that allow the researcher to make more general statements. Roland Barthes (1972) chose certain 'signs' of the French culture and in how far they convey information. For example, he described wrestling and whether there are specific cultural elements. In a similar way, the researcher wants to look at cupping and relate it to Minangkabau culture.

\section{Method}

The research method followed an ethnographic approach by conducting fieldwork. The usual way to conduct ethnography is participant observation (Gobo, 2008). However, in the case of healers, it was not possible to participate. Though, the researcher could observe the healing techniques. So, the modus operandi of the research process can be called non-participant observation. Furthermore, the researcher conducted lengthy and unstructured interviews due to the explorative nature of this research. It must also be mentioned that this research used some data from the $\mathrm{PhD}$ research of the author. However, in this research paper, the author uses a different perspective by using a semiotic point of view.

\subsection{Research Setting and Healers}

The research setting was a village community in the highlands of West Sumatra. During the research, the author looked at the type of healers who were practicing. Concise: Two main types of traditional healers were identified, namely the Islamic healers and traditional healers, who were called dukun. Amongst these two types, there were subcategories. Some healers treated all types of medical disorders, while others were specialists in either treating one type of medical disorder or using one type of treatment method. The latter type was the healers who used cupping (bekam). Cupping is a treatment that needed a special kind of skill, and so there were not many practitioners who used it. However, the other healers sometimes recommended that the patients consult them, particularly if they suffered from severe headaches or 
migraines.

\subsection{Characteristics of the Healers and Sampling Procedures}

It was already mentioned that this research was qualitative and used ethnography as its main research method. One village community was researched in depth. During the research process, it was discovered that two healers were specialists in using cupping. One healer was a member of the Islamic missionary group Jamaat Tabligh. He was no actual resident of the village, but from time to time, he passed by when he was active in his missionary activities, which mainly comprised encouraging the villagers to attend the five daily prayers in congregation. The other healer lived in the neighbouring village and was consulted by the villagers of the research setting as there was no specialist in cupping techniques in the village where the research was conducted. He lived in a remote hut outside. Such a remote place of residence was considered brave as many wild animals live in the nearby forest. He was a healer that got his knowledge from his father. The buffalo horns that were used in the cupping process have belonged to the family for many generations.

By contacting the healers, the researcher met patients too. Most of them allowed being observed during the cupping process. However, the researcher respected the local Islamic customs and did not observe female patients. Some of the patients were quite talkative and told their case stories. Nonetheless, for the researcher, the focus was to learn the cupping technique and analyse it.

\section{Results}

\subsection{Ethnographic Data}

The two healers who were observed used slightly different healing instruments. Nonetheless, both used horns. However, the traditional healer (dukun) used horns that are (according to his information) hundreds of years old. This means they are somehow related to the history of the village community. The healer of the Jamaat Tabligh used horns that were 'new'. Furthermore, the traditional healer (dukun) put the horns at the back of the head two times while the other healer did it only once.

The way the traditional healer conducts cupping is as follows (see also Stark, 2018): he shaves a small part of the hair at the back of the head of the patient. After that, he puts the horn on that place and sucks from the other side. The purpose is to create a vacuum. He seals the horn with the wax of the nest of a fly that is called galo-galo (see Plate 1).

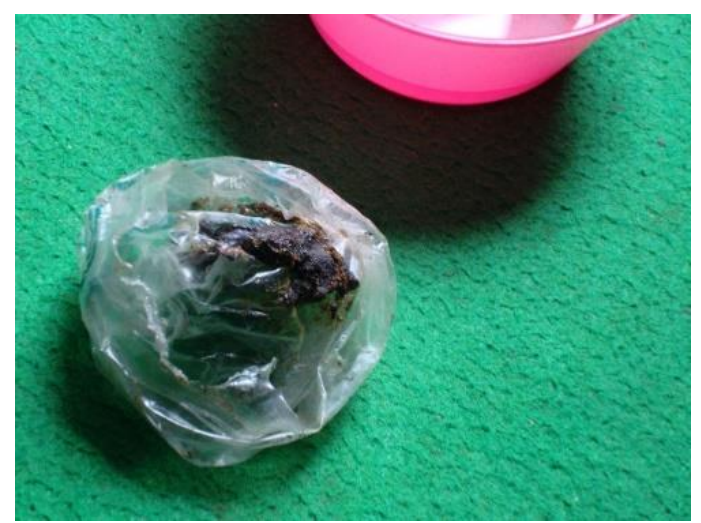

Plate 1. Wax of the nest of the galo-galo fly.

For the traditional healer, this wax is crucial. However, for the healer of the Islamic missionary group, it does not matter as he uses a 'normal' type of gum. It must be stressed that at this first time when he puts the horn at the back of the head, he does not scratch the skin at all. The aim is to collect the blood at this place. However, the Islamic healer skips this first step and starts directly with scratching the skin. The traditional healer waits until the horn falls down. Now, the healer scratches the skin with a simple knife or razor blade. Subsequently, the healer puts the horn in the same place. He creates a vacuum in the same way as he has done before. He waits until the vacuum disappears, and finally, he removes the blood. 


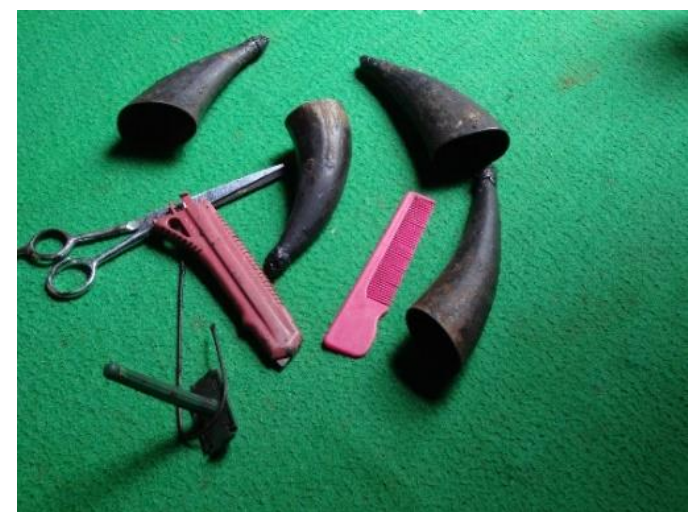

Plate 2. The Instruments that are used for Cupping (Stark, 2018, p. 217).

\section{Analysis}

For the analysis, it is necessary to look at the meaning of the buffalo in the Minangkabau culture. The term 'Minangkabau' itself can be examined. There are different interpretations of this term. Many people would derive the words from 'minang (menang)', which means 'to win', and 'kabau (kerbau)' that means buffalo. So, it would mean 'victorious buffalo'. This term is related to a legend which in simple words is as follows:

A long time ago, an army from outside (most likely from Java) wanted to invade the land of the Minangkabau. Though the opponents wanted to prevent a bloodbath and made a proposal: Instead of two armies, both groups should choose a buffalo that would fight against each other. So, the invaders chose a strong buffalo while the Minangkabau chose a small and very young buffalo that still needed to drink the milk of its mother. However, it was prevented from doing so. When the day of the battle began, the Minangkabau took a sharp object and attached it to the snout of the young buffalo. It ran to the strong buffalo when it was released and searched for milk. The sharp object killed the big buffalo, so the Minangkabau won the battle.

This story is well-known in the whole province of West Sumatra. Consequently, the buffalo has a special position within the Minangkabau culture. This fact can be seen in traditional architecture (Plate 3).

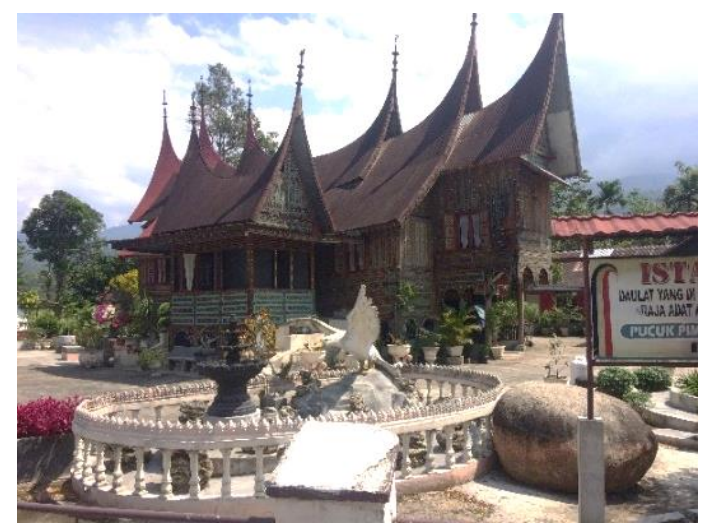

Plate 3. Traditional Architecture in West Sumatra

Many public and private buildings have a roof formed like a buffalo horn and remind the people that the buffalo has a special meaning for the regional culture. The house is not the only element, and there are others too. For example, there is a traditional headdress of women that has the form of a buffalo horn.

In chapter 3, the cupping technique is outlined in its major patterns. Interestingly, the traditional healer uses old horns that can be considered 'historic'. The whole cupping process resembles the events of the legendary battle. In the first stage, there is the awareness that there are 'invaders' that must be 'cast out'. The horn of the buffalo is used as a means of healing. It can be said that it is a sign that stands for the buffalo itself. At this point, it is necessary to define the term 'sign' and 'symbol'. In the sense of Ferdinand de Saussure, the sign makes an impression in our minds (Saussure, 1959). The sign consists of two parts, namely the signified and the signifier. If we have a word (like 'buffalo'), a certain 
picture arises in our mind (how a buffalo looks like). In the case of the healer, there is a horn that was taken from a buffalo. In the second stage, the healer scratches the skin, and it will bleed. The healer will stress that the harmful blood will come out and accumulate in the horn. In the end, the healer will throw it away. Edmund Leach emphasizes that there is a dyadic system between 'sender' and 'receiver' (Leach 1995, p.11). In the cupping case, the healer can be considered as the sender and the patient as the receiver. The cupping process resembles the legendary battle: The dangerous elements must be driven out. The buffalo horn is used, and a scratch leads to bleeding. Finally, the harmful elements will be thrown out. Somehow, this can be considered symbolic if we consider it as something that has a deeper meaning, and it is not interconnected at first sight.

In this discussion, it makes sense to look at Frederick Errington and how he characterizes the sign. For him, the sign has two features: a) the sign requires only little but not 'deep' interpretation (Errington, 1984, p. 32), and b) he cites Jung and states: "The sign is an abbreviated expression of a known thing. A symbol is always the best possible expression of a relatively unknown fact" (Errington, 1984, pp. 32-33).

Errington's characterization is important for further analysis. If we look at his first feature that the sign requires no 'deep' interpretation, then we must ask how the case of cupping is. For the patient, it is obvious that cupping leads to the removal of 'dirty' blood. However, the patient will not relate the blood to any other elements. Nevertheless, the cupping method in West Sumatra differs from the conventional cupping method that is used in many Islamic societies. First, there is no usage of fire to cause a vacuum. The healer in the village sucks at the horn to cause the vacuum. Nevertheless, it must be stressed that modern cupping sets do not use fire either. Second, the usage of the horns in the cupping process is something that cannot be found in the traditional Islamic cupping method. Normally the Islamic healer uses small glasses or cups. However, in this case, there are horns. So, this usage evokes feelings in the patients. However, it does not mean that the healer or patient undergo the legendary battle again (in their minds). That would be too far-fetched. The usage of horns merely means that a healing treatment with cupping uses an instrument of healing that is related to an important element of the Minangkabau culture and identity. In so far, it could help in the acceptance of the treatment itself.

For some people, it might be exaggerated to relate the healing method with the buffalo and the Minangkabau culture. But we must consider that intellectuals like Roland Barthes (1972) looked into signs and symbols, for example, a 'steak', and how it can 'say' something about French culture. In a similar way, we can look at the buffalo. It is a strong animal, and it was used in the past to plough the rice fields. In so far, it was related to food and the maintenance of life. So, it is not surprising if a healer uses the part of an animal that is connected with positive traits.

\section{Conclusion}

The researcher showed in this article that cupping is a traditional healing method that is used in the Indonesian province of West Sumatra. The cupping is quite particular as the healer uses buffalo horns. For the Minangkabau community, the buffalo is an animal that is relevant to their culture. The healer uses the horns as they were bequeathed from his forefathers. In this regard, it connects the horns with the history of the ancestors. Probably the horns were also used because they are resistant to humid tropical weather, and they would not break easily. Nonetheless, the correlation of the usage of buffalo horn in a healing method and the meaningfulness of such horns for the culture is remarkable and inspires to investigate it in a semiotic way. It stands for strength, life, and even the legendary battle. In this regard, it is used in a symbolic way.

In this research, it was also described that cupping is a traditional healing method that is used in the rural area of West Sumatra. Interestingly, the healers used it only at the back of the head. Although in many other societies, cupping is also used in other parts of the body. It is also remarkable that the described healers were men. It seems that they are in a certain 'position' in the matrilineal society. It is noteworthy that the horns were bequeathed from father to son, which means in a patrilineal way.

\section{References}

Aboushanab, T. S., \& AlSanad, S. (2018). Cupping Therapy: An Overview from a Modern Medicine Perspective. Journal of Accupuncture and Meridian Studies, 11(3), 83-87. https://doi.org/10.1016/j.jams.2018.02.001

Bahagian Perubatan Tradisional dan Komplementari (eds.) (2013). Garis Panduan Amalan Perubatan Tradisional \& Komplementari: Bekam. Kuala Lumpur: Kementerian Kesihatan Malaysia.

Barthes, R. (1972). Mythologies. New York: Noonday Press.

El Sayed, S. M., Mahmoud, H. S., \& Nabo, M. (2013). Medical and Scientific Bases of Wet Cupping Therapy (Al-hijamah): in Light of Modern Medicine and Prophetic Medicine. Alternative \& Integrative Medicine, 2(5), 1-16. Retrieved November 24, 2021, from https://www.hilarispublisher.com/open-access/medical-and-scientific-bases-of-wet-cupping-therapy-al-hijamah-in- 
light-of-modern-medicine-and-prophetic-medicine-2327-5162.1000122.pdf

Errington, F. K. (1984) Manners and Meaning in West-Sumatra. The Social Context Consciousness. New Haven/ London: Yale University Press.

Gobo, G. (2008). Doing Ethnography. Los Angeles/ London et al.: Sage.

Kahn, J. S. (1980). Minangkabau Social Formations. Indonesian Peasants and the World Economy. Cambridge/ London et. al.: Cambridge University Press. https://doi.org/10.1017/CBO9780511557552

Lajtai, L. (2003). The Minangkabau dukun. Tabula, 6(1), 117-134.

Leach, E. (1995). Culture \& Communication. The logic by which symbols are connected. London/ New York et al.: Cambridge University Press.

Nasir, P. E. et al. (2021), Minangkabau Matriliny and Gender Equality: Cultural Contribution to Sustainable Development Goals. Andalas Journal of International Studies, 10(1), 16-33. https://doi.org/10.25077/ajis.10.1.16-33.2021

Nessa, J. (1996). About Signs and Symptoms: Can Semiotics expand the View of Clinical Medicine. Theoretical Medicine, 17, 363-377. https://doi.org/10.1007/BF00489681

Risniati, Y., Afrilia, A. R., \& Lestari, T. W. et.al. (2019). Pelayanan Kesanan Tradisional Bekam: Kajian Mekanisme Keamanan dan Manfaat. Jurnal Penelitian dan Pengembangan Pealayanan Kesehatan, 3(3), 212-225. https://doi.org/10.22435/jpppk.v3i3.2658

Sanday, P. R. (2002). Women at the Center. Life in a Modern Matriarchy. Ithaca, NY: Cornell University Press.

Saussure, F. (1959). Course in General Linguistics. New York: Columbia University Press.

Stark, A. (2018). The Minangkabau Healers and Healing Methods: A Structural Analysis. Penang: Unpublished PhD Thesis Universiti Sains Malaysia.

Stark, A. (2019). Traditional Medicine in West Sumatra: Some General Features. Studies on Ethno-Medicine, 13(3), 131-137. https://doi.org/10.31901/24566772.2019/13.03.587

\section{Copyrights}

Copyright for this article is retained by the author(s), with first publication rights granted to the journal.

This is an open-access article distributed under the terms and conditions of the Creative Commons Attribution license which permits unrestricted use, distribution, and reproduction in any medium, provided the original work is properly cited. 